\title{
Maturity testing of 3D printing concrete with inert microfiller
}

\author{
Szymon Skibicki ${ }^{1}$, Maria Kaszyńska ${ }^{1}$, and Mateusz Techman ${ }^{1, *}$ \\ ${ }^{1}$ West Pomeranian University of Technology, Faculty of Civil Engineering and Architecture, \\ Piastów 50, 70-311 Szczecin, Poland
}

\begin{abstract}
The 3D Printing of cement composites is one of the fastest developing technologies of modern concrete. The 3D printing involves concretes with high amounts of microfillers. The study analyses the influence of curing conditions on the development of strength of concretes applicable in 3D printing. Ten mixes were tested in the study. In the studied cases cement constituted to $50 \%$ of the mass, while microfillers such as lime stone powder, kaolin, quartz powder and sand (up to $2 \mathrm{~mm}$ ) constituted to the rest of the mass. Samples were cured for 7 days in exothermic conditions at $5^{\circ} \mathrm{C}, 20^{\circ} \mathrm{C}, 35^{\circ} \mathrm{C}$. Standard mortar samples of $4 \times 4 \times 16 \mathrm{~cm}$ and cylinders with $46.5 \mathrm{~mm}$ and height of $35 \mathrm{~mm}$ that simulate the printed 3D path were made. The compressive strength was tested after $12 \mathrm{~h}, 24 \mathrm{~h}, 48 \mathrm{~h}, 72 \mathrm{~h}, 168 \mathrm{~h}$ and 28 days. Based on the acquired results the temperature development function was formulated and activation energy was determined. The results showed that the proposed method is useful in evaluation of printed concrete curing. It can be also used to determine the time of loading the wall which can speed up the process of constructing while maintaining degree of safety.
\end{abstract}

\section{Introduction}

A strong focus placed by various research facilities on 3D concrete printing has resulted in a development of many new research methods of this novel constructing system [1-4]. However, there are still no established Standards defining requirements for this technology. The elements created by additive manufacturing show small cross-section, which causes them to adopt the external temperature rapidly. As a results the elements can be highly susceptible to changes in strength development caused by low or high temperatures.

The influence of temperature on the mechanical properties of ordinary concrete is well researched $[5,6]$. The correlation between temperature of curing and mechanical properties is used daily in civil engineering (maturity method). This correlation allows to predict the strength of concrete, which results in shorter striking time or faster loading. Premature striking of the formwork was a cause of numerous structural failures and collapses [5]. The 3D printing technology is issued with a similar problem of strength prediction in structures. Applying well known and widely used maturity method allows to determine the loading time (i.e. with upper floors) even in structures constructed by additive manufacturing. Currently only one research facility tries to address the issue [7]. 
The research was conducted on concretes with inert microfillers applicable in 3D printing due to their rheological properties and composition. For proposed mixes the apparent activation energy, coefficients of strength improvement for different temperatures, cross-over effect and equivalent time were determined. The study was conducted on standard samples and model samples similar to printed ones $[4,8]$.

\section{Background}

\subsection{Maturity method}

The maturity method is directed to determine mechanical properties of concrete based on the measurements of temperature during curing $[5,9]$. The maturity method was firstly used in 1949 by Nurse [10] and MacIntosha [11]. The studies were continued by Saul [12] in 1951. The determined function was based on the so-called maturity index (1). Initially used function did not reflect correctly the reality. As soon as in 1977 a research team have proposed an Arhennius equation for better projection of concrete curing. To concur the research a so called equivalent time was proposed (2). Many researchers (inter alia Carino [13], Kaszyńska [14]) proved that the equation (2) better reflects the maturity of concrete in structures than the Saul's formula (1).

The maturity method evolved with following years and have derived into different functions and methods for determining the mechanical properties of concrete [13,15-18]. Today the most popular version is included in the American Standard ASTM C1074 [19], which was proposed by Carino [13]. The method has a wide practical application [20]. The aforementioned equation from ASTM C1074 is seen as (3).

$$
M=\sum_{0}^{t}\left(T-T_{0}\right) \cdot \Delta t
$$

where:

$M \quad$ maturity index $\left[{ }^{\circ} \mathrm{C}\right.$-hours or ${ }^{\circ} \mathrm{C}$-days $]$,

$T$ average concrete temperature during the time interval $\Delta t\left[{ }^{\circ} \mathrm{C}\right]$,

$T_{0} \quad$ datum temperature (usually assumed to be $-10^{\circ} \mathrm{C}$ ),

$t \quad$ elapsed time [hours or days],

$\Delta t \quad$ time interval [hours or days].

$$
t_{e}=\sum_{0}^{t} \exp \left[\frac{-E_{a}}{R} \cdot\left(\frac{1}{T}-\frac{1}{T_{r}}\right)\right] \cdot \Delta t
$$

where:

$t_{e} \quad$ the equivalent age at the reference temperature,

$E_{a} \quad$ apparent activation energy $\left[\frac{\mathrm{J}}{\mathrm{mol}}\right]$,

$R \quad$ universal gas constant, $8.314\left[\frac{\mathrm{J}}{\mathrm{mol} \cdot \mathrm{K}}\right]$,

$T \quad$ average absolute temperature of the concrete during interval $\Delta t[\mathrm{~K}]$,

$T_{r} \quad$ absolute reference temperature $[\mathrm{K}]$.

$$
\mathrm{S}=S_{u} \cdot \frac{k \cdot\left(t-t_{0}\right)}{1+k \cdot\left(t-t_{0}\right)}
$$

where:

$k$ rate constant, $[1 / h] t_{0}$-age at start of strength development,

$t$ elapsed time. 


\subsection{D printing - size specimen problem}

There is only a single study that tried to evaluate the applicability of maturity method for optimization of 3D printing [7]. However, it is an overview article, that does not present any computations of coefficients found in (1)-(3).

Currently there are no Standards for applicability of the mixes for 3D printing. Many research facilities [4,21-24] proposed own methods that require a printing device. The methods seem well-thought and clearly evaluate the applicability of the mix. However, they are costly and time consuming.

Several research facilities have proposed a framework for estimation of mix feasibility in $3 \mathrm{D}$ printing. A research team [8] proposed a test on a $\Phi 60 \times 35 \mathrm{~mm}$ samples in a specially designed test bench. The samples are loaded with several weights that simulate additional printed layers. A research team [4] proposed a cylinder stability test, which is conducted on a $\Phi 60 \times 40 \mathrm{~mm}$ samples with a $5.5 \mathrm{~kg}$ applied load. The second method also determines the deformation of the sample. The size of the deformation determines the readiness of the mix for printing. A research team [2] determines the usability of the mix based on a slump flow [21]. Other teams [8,25] determine the usability with standard rheological tests conducted in a set period of time.

\section{Materials and experimental procedure}

\subsection{Mix compositions}

The mixes were made using 50\% of CEM I $52.5 \mathrm{R}$ (Rapid Portland Cement, according to European Standard) and $50 \%$ consisting of various microfillers including quartz powder (QP), limestone powder (LP), kaolin (K) and fine aggregate (FA). SP was added in percentage of cement mass to reach required consistency according to $[21,26]$. Those 4 fillers were added in various combinations. Designed mixes are presented in Table 1. The water/cement ratio was set to 0.42 . The mix consistency was regulated with a superplasticizer.

It should be noticed that these type of mixes are used in French research facilities [8,27] to $3 \mathrm{D}$ printing. The „LP/K” mix and its properties was presented in other studies [8] as a applicable 3D printing mix. The authors have confirmed the properties of the above mentioned mixes on their own.

Table 1. Mix compositions.

\begin{tabular}{|c|c|c|c|c|c|c|c|}
\hline \multirow[t]{2}{*}{ Mix } & $\sum_{\substack{u \\
\text { in }}} \underset{n}{n}$ & वे & 党 & 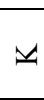 & 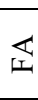 & \multirow{2}{*}{$\frac{U}{3}$} & \multirow{2}{*}{$\begin{array}{l}\text { है } \\
\text { do } \\
\%\end{array}$} \\
\hline & \multicolumn{5}{|c|}{$\%$} & & \\
\hline QP & \multirow{10}{*}{ X } & $X$ & - & - & - & 0.42 & $0.80 \%$ \\
\hline LP & & - & $\mathrm{X}$ & - & - & 0.42 & $0.68 \%$ \\
\hline $\mathrm{K}$ & & - & - & $\mathrm{X}$ & - & 0.49 & $2.16 \%$ \\
\hline$\overline{\text { FA }}$ & & - & - & - & $\mathrm{X}$ & 0.34 & $0.00 \%$ \\
\hline $\mathrm{QP} / \mathrm{LP}$ & & $X$ & $X$ & - & - & 0.42 & $0.80 \%$ \\
\hline $\mathrm{QP} / \mathrm{K}$ & & $X$ & - & $\mathrm{X}$ & - & 0.42 & $1.08 \%$ \\
\hline QP/FA & & $X$ & - & - & $X$ & 0.42 & $0.17 \%$ \\
\hline $\mathrm{LP} / \mathrm{K}$ & & - & $\mathrm{X}$ & $\mathrm{X}$ & - & 0.43 & $2.16 \%$ \\
\hline LP/FA & & - & $\mathrm{X}$ & - & X & 0.42 & $0.00 \%$ \\
\hline $\mathrm{K} / \mathrm{FA}$ & & - & - & $\mathrm{X}$ & $\mathrm{X}$ & 0.42 & $0.34 \%$ \\
\hline
\end{tabular}




\subsection{Experimental procedure}

After mixing, the concrete samples were placed in a climatic chamber and stored for 7 days in 3 different temperatures of $5^{\circ} \mathrm{C}, 20^{\circ} \mathrm{C}, 35^{\circ} \mathrm{C}$. After the first stage the samples were stored in a laboratory conditions at $20^{\circ} \mathrm{C} \pm 2^{\circ}$. Two types of samples were prepared including 40x40x160 mm standard samples and cylindrical samples with diameter of $46.5 \mathrm{~mm}$ and height of $35 \mathrm{~mm}$ that simulated a shape of printed layers.

Table 2. Parameters of maturity function.

\begin{tabular}{|c|c|c|c|c|c|c|c|}
\hline $\mathrm{T}\left[{ }^{\circ} \mathrm{C}\right]$ & 5 & 20 & 35 & \multirow{2}{*}{$\begin{array}{c}\mathrm{T}_{0} \\
{\left[{ }^{\circ} \mathrm{C}\right]}\end{array}$} & \multirow{2}{*}{$\begin{array}{l}\mathrm{E} / \mathrm{R} \\
{\left[{ }^{\circ} \mathrm{K}\right]}\end{array}$} & \multirow{2}{*}{$\begin{array}{c}\mathrm{E} \\
{[\mathrm{J} / \mathrm{mol}]}\end{array}$} & \multirow{2}{*}{$\mathrm{R}^{2}$} \\
\hline Mix & & $\mathrm{k}[-]$ & & & & & \\
\hline LP K & 0.035 & 0.076 & 2.035 & 2.16 & 5231 & 43492 & 0.98 \\
\hline LP_FA & 0.036 & 0.065 & 2.144 & 1.19 & 4766 & 39623 & 0.96 \\
\hline QP LP & 0.032 & 0.054 & 0.355 & -2.21 & 3943 & 32779 & 0.97 \\
\hline K FA & 0.026 & 0.054 & 0.144 & -1.23 & 4373 & 36356 & 1.00 \\
\hline QP_K & 0.027 & 0.026 & 0.093 & 2.48 & 4465 & 37120 & 0.70 \\
\hline QP FA & 0.026 & 0.067 & 0.304 & -3.62 & 4206 & 34967 & 0.98 \\
\hline FA & 0.036 & 0.114 & 0.045 & -0.42 & 5124 & 42603 & 0.98 \\
\hline LP & 0.029 & 0.059 & 0.315 & -3.91 & 3903 & 32448 & 1.00 \\
\hline $\mathrm{K}$ & 0.021 & 0.024 & 0.047 & -0.07 & 3993 & 33202 & 0.80 \\
\hline QP & 0.028 & 0.045 & 0.550 & -1.20 & 4066 & 33806 & 0.94 \\
\hline
\end{tabular}

\section{Test results}

\subsection{Compressive strength development}

Compressive strength of concrete samples was tested after 12, 24, 48, 72, 168 and 672 hours. The test results are presented in Fig.1. There are the mean values calculated based on 4 measurements (cube specimens). Coefficient of Variation for the analysed specimen was lower than $4.58 \%$. The highest compressive strength was reached by QP, QP/FA, QP/LP and LP/FA, while the lowest by $\mathrm{K}$ concrete.

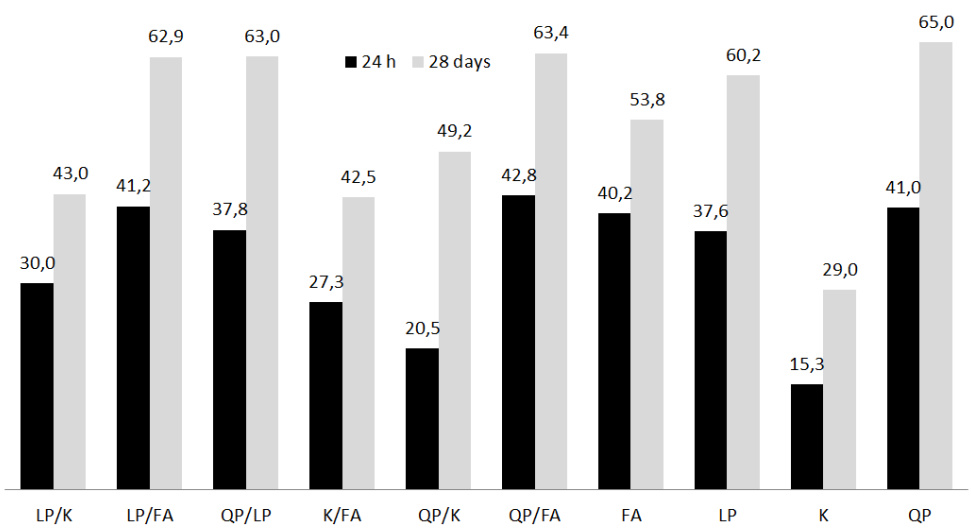

Fig. 1. Compressive strength of concretes after $24 \mathrm{~h}$ and 28 days.

The analysis determined the cube/cylinder compressive strength ratio $\left(f_{\text {c.cube }} / f_{\text {c,cylinder }}\right)$. Values of compressive strength were obtained at 28 day-age after curing at $20^{\circ} \mathrm{C}$. Mean value of $f_{\text {c.cube }} / f_{\text {c,cylinder }}$ is 1.74 with coefficient of variation of $3.93 \%$. Differences between 
cube and cylinder specimen are noticeable. Cylindrical specimens exhibit lower compressive strength.

The study focuses on 4 mixes (LP/K, QP/FA, QP/LP and LP/FA). Figure 2 and 3 present the strength development curves of selected mixes.
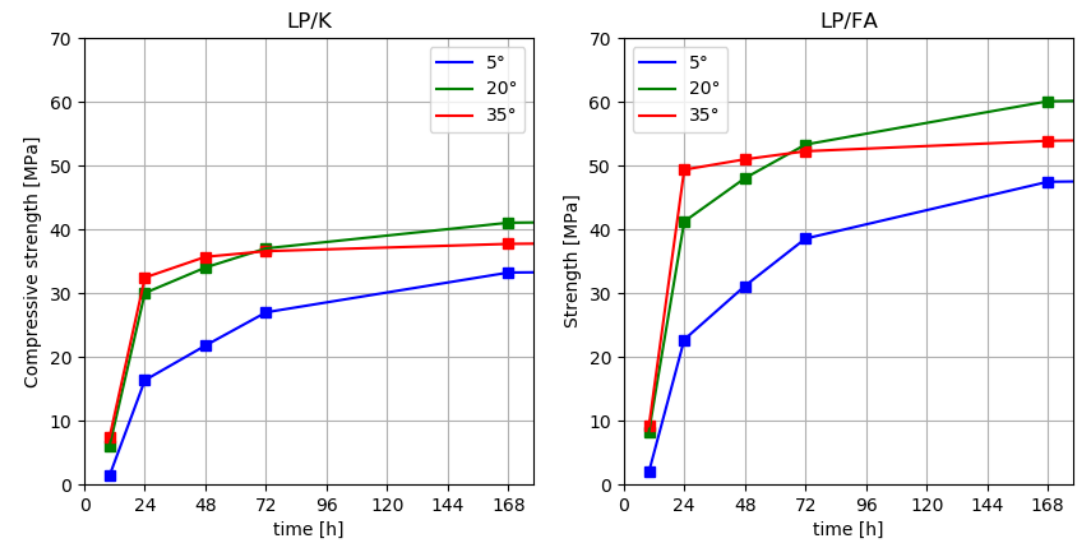

Fig. 2. Compressive strength development of LP/K and LP/FA cured in different temperatures.
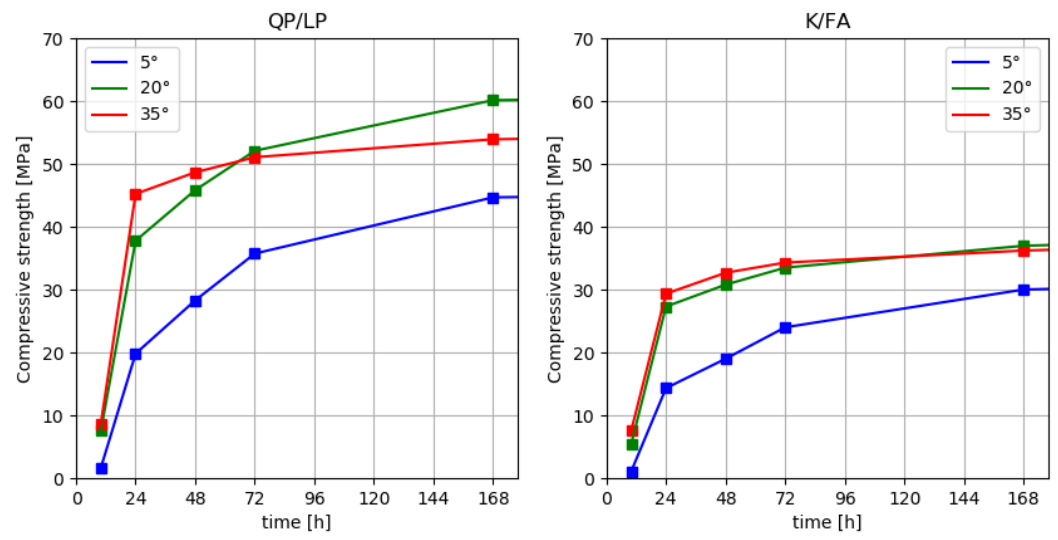

Fig. 3. Compressive strength development of QP/LP and K/FA cured in different temperatures.

\subsection{Apparent activation energy}

Apparent activation energy $\left(\mathrm{E}_{\mathrm{a}}\right)$ was established in accordance with A1.1.8.2 of ASTM C1074-11. Table 2 contains the values of $k$ (rate constant) coefficient, $T_{0}$ (datum temperature), $\mathrm{E}_{\mathrm{a}}$ and $\mathrm{R}^{2}$ (determination coefficient). The results show that $\mathrm{E}_{\mathrm{a}}$ ranges from 34 to $44 \mathrm{~kJ} / \mathrm{mol}$. The values of $\mathrm{E}_{\mathrm{a}}$ between $34-44 \mathrm{~kJ} / \mathrm{mol}$ are corresponding for this type of cement binder [28].

\subsection{Equivalent time}

For selected mixes an equivalent time was calculated based on the results in Table 2 and equation (4) (transformed formula (3)). Figure 4 shows equivalent time which is needed to reach $10 \%, 20 \%, 40 \%, 80 \%$ of ultimate compressive strength of concrete cured at $20^{\circ} \mathrm{C}$ $\left(S_{20} / S_{u, 20^{\circ}}\right)$. Figure 4 shows the results for selected mixes cured at different temperatures. 


$$
\mathrm{t}_{e, 5^{\circ} / 35^{\circ}}=t_{0}-\frac{S_{20^{\circ}}}{k \cdot\left(S_{20^{\circ}}-S_{u}\right)}
$$

where:
$S_{20^{\circ}}$ strength which respond $0,1 / 0.2 / 0.4$ or 0.8 of ultimate compressive strength in
$S_{u}$
$k$ $20^{\circ} \mathrm{C}$, compressive strength in $5^{\circ}$ or $35^{\circ}$,
$[1 / h] t_{0} \quad$ tiem at start of strength development in temperature $5^{\circ}$ or $35^{\circ}$,
$t_{e, 5^{\circ}} / \mathrm{t}_{\mathrm{e}, 35^{\circ}} \quad$ equivalent time which is needed to reach strength threshold $\left(S / S_{u, 20^{\circ}}=0.1 / 0.2 /\right.$ $0.4 / 0.8)$ in temperature $5^{\circ} \mathrm{C}$ or $35^{\circ} \mathrm{C}$.

The difference in equivalent time is important in the early stages of concrete curing when the concrete has not yet developed full strength. In such a case, prematurely loaded structure might collapse [5]. During the first stage of curing up to $\mathrm{S} / \mathrm{S}_{\mathrm{u}}=0.4$ the development rate of strength is slower in low temperature $\left(5^{\circ} \mathrm{C}\right)$ causing significant differences in $t_{e}$. For example for mix K/FA difference at $\mathrm{S} / \mathrm{S}_{\mathrm{u}}=0.2$ was $6.3 \mathrm{~h}$. This time seems short but in additive manufacturing even $6 \mathrm{~h}$ is significant. In later stages (after $\mathrm{S} / \mathrm{S}_{\mathrm{u}}=0.4$ ) the differences are lowered, but are not so important considering relatively high concrete strength. Another issue occurring during curing is a cross-over effect, described below.

Studied mixes have exhibited a visible cross-over effect (Fig.1, Fig.2). Strength development rate in different temperatures changes during curing which was already studied elsewhere $[29,30]$. Concretes with high amounts of cement or with rapid cements are strongly susceptible to the effect. Additionally, the higher temperature the more significant the differences in a final strength of concrete. In studied mixes the cross-over effect was visible between 30-90 hours. For mixes with fine aggregate (FA) and with kaolin (K) with different $\mathrm{w} / \mathrm{c}$ ratio the effect has not occurred at all.
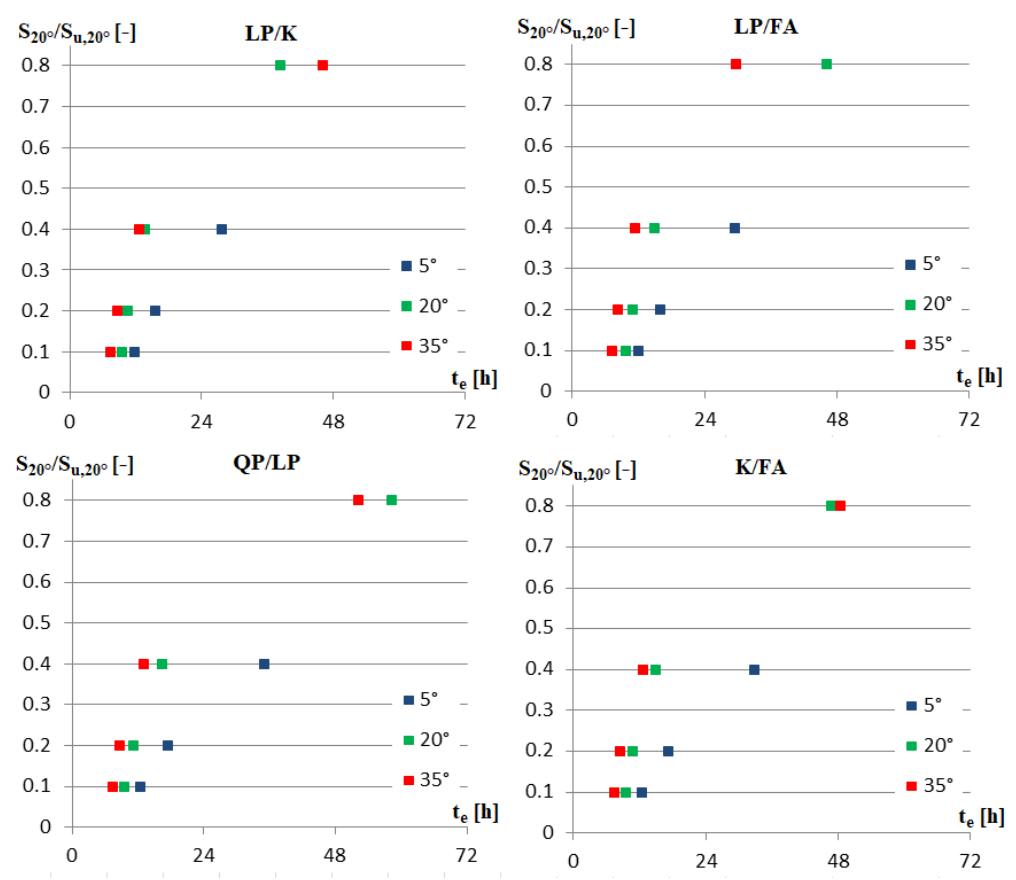

Fig. 4. Equivalent time for different compressive strength thresholds. 


\section{Conclusion}

The conducted study has verified the composition of mixes with mineral additives suitable fo 3D printing. Highest compressive strength was obtained by QP, QP/FA, QP/LP and LP/FA concretes with addition of quartz and limestone powder, while the lowest by $\mathrm{K}$ concrete with kaolin.

The study focuses on the influence of temperature on the development of compressive strength. Two temperatures simulating conditions in spring-autumn $\left(\mathrm{T}=5^{\circ} \mathrm{C}\right)$ and summer $\left(\mathrm{T}=35^{\circ} \mathrm{C}\right)$ were taken into consideration. The influence of temperature was analyzed using maturity method. The study allowed to determine the values of activation energy for the mixes with mineral fillers and rapid Portland cement CEM I $52.5 \mathrm{R}$. This allowed to calculated the equivalent curing time and evaluation of compressive strength for different curing temperatures. Study has shown that in the case of 8 concretes the so-called crossover effect occurred. The phenomenon occurs as decline in compressive strength development rate after 3 days in concretes cured in higher temperatures.

The study has shown that compressive strength of cylindrical samples that simulate printed layers is significantly lower than compressive strength of standard cubical samples $10 \times 10 \times 10 \mathrm{~cm}$.

\section{References}

1. T. Wangler, E. Lloret, L. Reiter, N. Hack, F. Gramazio, M. Kohler, M. Bernhard, B. Dillenburger, J. Buchli, N. Roussel, et al., Digital Concrete: Opportunities and Challenges. RILEM Letters, 1, 67-75 (2016)

2. F. Bos, R. Wolfs, Z. Ahmed, T. Salet, Additive manufacturing of concrete in construction: Potentials and challenges of 3D concrete printing. Virtual and Physical Prototyping, 11, 1-17 (2016)

3. Y. Tay, B. Panda, S. Paul, N. Noor Mohamed, M. Tan, K. Leong, 3D printing trends in building and construction industry: A review. Virtual and Physical Prototyping, 12, 117 (2017)

4. A. Kazemian, X. Yuan, E. Cochran, B. Khoshnevis, Cementitious materials for construction-scale 3D printing: Laboratory testing of fresh printing mixture. Construction and Building Materials, 145, 639-647 (2017)

5. N. Carino, H. Lew, The Maturity Method: From Theory to Application. In Structures 2001; Chang, P., Ed.: American Society of Civil Engineers: Reston, VA, 1-19 (2001)

6. S. Skibicki, Optimization of Cost of Building with Concrete Slabs Based on the Maturity Method. IOP Conf. Ser.: Mater. Sci. Eng., 245, 1-11 (2017)

7. R.J.M. Wolfs. $3 d$ printind of concrete structures (graduation thesis): Eindhoven University of Technology, 1-110 (2015)

8. A. Perrot, D. Rangeard, A. Pierre, Structural built-up of cement-based materials used for 3D-printing extrusion techniques. Mater Struct, 49, 1213-1220 (2016)

9. Mariak A., Wilde K., Wyznaczanie wytrzymałości betonu na podstawie funkcji dojrzałości wg amerykańskiej normy ASTM C1074-11. Materiały Budowlane, 4, 6871 (2015)

10. R. Nurse, Steam curing of concrete. Mag Concrete Res, 2, 79-88 (1949)

11. J. McIntosh, Electrical curing of concrete. Mag Concrete Res, 1, 21-28 (1949)

12. A. Saul, Principles underlying the steam curing of concrete at atmospheric pressure. Mag Concrete Res, 2, 127-140 (1951) 
13. R. Tank, R. Carino, Rate Constant Functions for Strength Development of Concrete. ACI Materials Journal, 88 (1), 74-83 (1991)

14. M. Kaszynska, Early age properties of high-strength/high-performance concrete. Cement and Concrete Composites, 24, 253-261 (2002)

15. H. Freiesleben, P. Pedersen, Curing of Concrete Structures. CEB Information Bulletin, 166, 1-42 (1985)

16. J. Zhang, D. Cusson, P. Monteiro, J. Harvey, New perspectives on maturity method and approach for high performance concrete applications. Cement and Concrete Research, 38, 1436-1446 (2008)

17. Knudsen T., The dispersion model for hydration of Portland cement: I. General concepts. Cement and Concrete Research, 14, 622-630 (1984)

18. P. Fjellström, J.-E. Jonasson, M. Emborg, H. and Hedlund, Model for Concrete Strength Development Including Strength Reduction at Elevated Temperatures. Nordic Concrete Research, 45/1, 25-44 (2012)

19. ASTM C1074-11. Standard Practice for Estimating Concrete Strength by the Maturity Method.

20. J. Myers. The Use of Maturity Methods as a Quality Control Tool for High Performance Concrete Bridge Decks: PCI / FHWA / FIB International Symposium on High Performance Concrete, 1-18 (2000)

21. G. Ma, Z. Li, L. Wang, Printable properties of cementitious material containing copper tailings for extrusion based 3D printing. Construction and Building Materials, 162, 613-627 (2018)

22. T. Le, S. Austin, S. Lim, R. Buswell, R. Law, A.G.F. Gibb, T. Thorpe, Hardened properties of high-performance printing concrete. Cement and Concrete Research, 42, 558-566 (2012)

23. E. Secrieru, S. Fataei, C. Schröfl, V. Mechtcherine, Study on concrete pumpability combining different laboratory tools and linkage to rheology. Construction and Building Materials, 144, 451-461 (2017)

24. Z. Malaeb, H. Hachem, A. Tourbah, T. Maalouf, El Zarwi N., Hamzeh F., 3d concrete printing: Machine and mix design. International Journal of Civil Engineering and Technology (IJCIET), 6, 14-22 (2015)

25. N. Roussel, F. Cussigh, Distinct-layer casting of SCC: The mechanical consequences of thixotropy. Cement and Concrete Research, 38, 624-632 (2008)

26. G. Ma, L. Wang, A critical review of preparation design and workability measurement of concrete material for largescale 3D printing. Front. Struct. Civ. Eng., 22, 382-400 (2017)

27. C. Gosselin, R. Duballet, P. Roux, N. Gaudillière, J. Dirrenberger, P. Morel, Largescale $3 \mathrm{D}$ printing of ultra-high performance concrete - a new processing route for architects and builders. Materials \& Design, 100, 102-109 (2016)

28. Pinto R.C.A., Schindler A.K., Unified modeling of setting and strength development. Cement and Concrete Research, 40, 58-65 (2010)

29. Wade, S.A.; Schindler, A.K.; Barnes, R.W.; Nixon, J.M., Eds. Maturity Method Report No. 1: Highway Research Center and Department of Civil Engineering at Auburn University, 1-307 (2006)

30. Brooks A.G., Schindler A.K., Barnes R.W., Maturity Method Evaluated for Various Cementitious Materials. Journal of Mat. in Civil Engineering, 19, 1017-1025 (2007) 